\title{
ANALYSIS OF THE CAPABILITIES OF LOW FREQUENCY GROUND PENETRATING RADAR FOR CAVITIES DETECTION IN ROUGH TERRAIN CONDITIONS: THE CASE OF DIVAČA CAVE, SLOVENIA
}

\author{
ANALIZA ZMOŽNOSTI NIZKOFREKVENČNEGA GEORADARJA ZA \\ ZAZNAVANJE JAM NA TEŽKO PREHODNEM POVRŠJU: PRIMER \\ DIVAŠKE JAME, SLOVENIJA
}

\author{
Andrej GOSAR ${ }^{1}$
}

\begin{abstract}
UDC 550.837.7:551.435.84(497.4)
Andrej Gosar: Analysis of the capabilities of low frequency ground penetrating radar for cavities detection in rough terrain conditions: The case of Divača cave, Slovenia

High frequency ground penetrating radar (GPR) is usually applied for cavities detection in a shallow subsurface of karst areas to prevent geotechnical hazards. For specific projects, such as tunnel construction, it is important to detect also larger voids at medium depth range. However, dimensions of classical rigid low frequency antennas seriously limit their applicability in a rough terrain with dense vegetation commonly encountered in a karst. In this study recently developed $50 \mathrm{MHz}$ antennas designed in a tube form were tested to detect cave gallery at the depth between $12 \mathrm{~m}$ and $60 \mathrm{~m}$. The Divača cave was selected because of a wide range of depths under the surface, possibility of unknown galleries in the vicinity and a rough terrain surface typical for Slovenian karst. Seven GPR profiles were measured across the main gallery of the cave and additional four profiles $\mathrm{NE}$ of the cave entrance where no galleries are known. Different acquisition and processing parameters were analysed together with the data resolution issues. The main gallery of the cave was clearly imaged in the part where the roof of the gallery is located at the depth from $10 \mathrm{~m}$ to $30 \mathrm{~m}$. The width of the open space is mainly around $10 \mathrm{~m}$. Applied system was not able to detect the gallery in the part where it is located deeper than 40 $\mathrm{m}$, but several shallower cavities were discovered which were unknown before. The most important result is that the profiles acquired NE of the cave entrance revealed very clearly the existence of an unknown gallery which is located at the depth between $15 \mathrm{~m}$ and $22 \mathrm{~m}$ and represents the continuation of the Divača cave. Access to this gallery is blocked by the sediment fill in the entrance shaft of the cave. The results of the study are important also for future infrastructure projects which will involve construction of tunnels through karstified limestone and for speleological investigations to direct the research efforts. Izvleček UDK 550.837.7:551.435.84(497.4) Andrej Gosar: Analiza zmožnosti nizkofrekvenčnega georadarja za zaznavanje jam na težko prehodnem površju: primer Divaške jame, Slovenija

Za zaznavanje jam plitvo pod površjem se pri preprečevanju geotehničnih nevarnosti na kraških območjih navadno uporablja visokofrekvenčni georadar. Pri posebnih gradnjah kot so predori, pa je pomembno zaznati tudi večje praznine v srednje velikih globinah. Velikost klasičnih nizkofrekvenčnih georadarskih anten pa močno omejuje njihovo uporabnost na težko prehodnih območjih z gosto vegetacijo, ki so zelo pogosta na krasu. V tej študiji je bila preizkušena novo-razvita $50 \mathrm{MHz}$ antena cevaste oblike za zaznavanje jamskega rova na globini med $12 \mathrm{~m}$ in $60 \mathrm{~m}$. Izbrana je bila Divaška jama, in sicer zaradi širokega razpona globin rova pod površjem, možnostjo za obstoj še neodkritih rovov in težko prehodnega površja, značilnega za slovenski kras. Izmerjeno je bilo sedem georadarskih profilov prek glavnega jamskega rova in dodatni štirje profili SV od vhoda v jamo, kjer še ni znanih rovov. Analizirani so različni parametri terenskih meritev in obdelave podatkov, skupaj z njihovo ločljivostjo. Glavni jamski rov se zelo jasno odraža na georadarskih profilih na območju, kjer se strop nahaja v globini med $10 \mathrm{~m}$ in $30 \mathrm{~m}$, širina rova pa je okoli $10 \mathrm{~m}$. Uporabljen georadarski sistem pa ni bil zmožen zaznati jamskega rova tam, kjer se ta nahaja globlje od $40 \mathrm{~m}$. Zaznane pa so bile številne plitvejše kaverne ali rovi, ki pred tem niso bili znani. Najpomembnejši rezultat raziskave je, da je bil odkrit še neznan rov SV od jamskega vhoda. Rov se nahaja v globini med $15 \mathrm{~m}$ in $22 \mathrm{~m}$ in predstavlja nadaljevanje Divaške jame. Dostop do rova preprečujejo sedimenti na dnu vhodnega brezna. Rezultati imajo pomen tudi za prihodnje infrastrukturne projekte, ki bodo vključevali izgradnjo predorov skozi zakrasel apnenec in za speleološke raziskave pri njihovem usmerjanju. Ključne besede: georadar, zaznavanje jam, prostorska ločljivost, apnenec, Divaška jama.
\end{abstract}

Keywords: ground penetrating radar, cavity detection, spatial

resolution, limestone, Divača cave.

${ }^{1}$ University of Ljubljana, Faculty of Natural Sciences and Engineering; Environment Agency of Slovenia, Seismology and Geology Office, Dunajska cesta 47, SI-1000 Ljubljana, Slovenia, e-mail: andrej.gosar@gov.si

Received/Prejeto: 5.12 .2011

ACTA CARSOLOGICA 41/1, 77-88, POSTOJNA 2012 


\section{INTRODUCTION}

Cavity detection is one of primary objectives of geophysical investigations in karst regions. Commonly applied geophysical techniques for this purpose include gravity method, electrical resistivity imaging, seismic refraction and ground penetrating radar (GPR) (Mareš et al. 1997; Reynolds 1997). Especially GPR has become in the last 15 years the most important method for shallow investigations, because different conditions for its successful application are usually favourable in karst. Some applications described in literature are related to shallow depth penetration which rarely exceeds 5-8 $\mathrm{m}$ using GPR systems with high frequency antennas, usually between $200 \mathrm{MHz}$ and $500 \mathrm{MHz}$ (Chamberlain et al. 2000; Knez \& Slabe 2005; Pavlič \& Praznik 2011). There are at least two reasons for this. The first is that most investigations are aimed to assess geotechnical hazards for different constructions on the surface, which are in karst related to the danger of the sudden collapse of the ground or to the activation of a sinkhole, both related to shallow hidden cavities. Second reason is that karst surface is usually very rough and measurements using small high frequency systems in which both transmitting and receiving antenna are integrated in a common case, are much easier.

However, sometimes there is a need to detect also larger cavities at greater depths in karst areas. This is especially important for projects which involve tunnel constructions or for speleological purposes when we want to discover a continuation of a known cave, but the access to new galleries is blocked by a collapsed material or other sediment fill, flowstone or too narrow passages. Low frequency antennas in the range from $25 \mathrm{MHz}$ to $100 \mathrm{MHz}$ should be applied for this purpose to achieve the depth penetration down to $20-30 \mathrm{~m}$ or even $40-50 \mathrm{~m}$. The dimensions (length) of classical unshielded antennas are from $1 \mathrm{~m}$ for $100 \mathrm{MHz}$ to $4 \mathrm{~m}$ for $25 \mathrm{MHz}$ and the weight of each $50 \mathrm{MHz}$ antenna for instance is close to $3 \mathrm{~kg}$. During the acquisition, transmitting and receiving antenna should be spaced from $2 \mathrm{~m}$ to $6 \mathrm{~m}$, which requires a system of rigid handles and horizontal connection bars. Therefore, it is very difficult to move a rigid system of two properly spaced large antennas across a rough terrain and impossible through the dense vegetation common in karst, or extensive clearing of the profile route is necessary prior to the survey. The additional problem is to assure a good contact of long rigid antennas with the ground on a rough terrain. These are all reasons why there are only few reports on low frequency GPR applications in karst areas. Recent development of special rough terrain antennas (RTA) has only enabled application of low frequency GPR measurements in realistic conditions.

The purpose of this study is to analyse the capabilities of low frequency GPR with RTA for cavities detection in a medium depth range and rough terrain conditions. The main issue to be tested is the penetration depth, since rather different values between $25 \mathrm{~m}$ and $40 \mathrm{~m}$ are reported by different authors for different geological conditions (Reynolds 1997; Daniels 2004; Jol 2009). The second important issue is the horizontal resolution, as it is well known that resolution in realistic conditions can be significantly different from the theoretical estimations. For testing we selected the Divača cave in SW Slovenia (Fig. 1) which has accessible galleries in

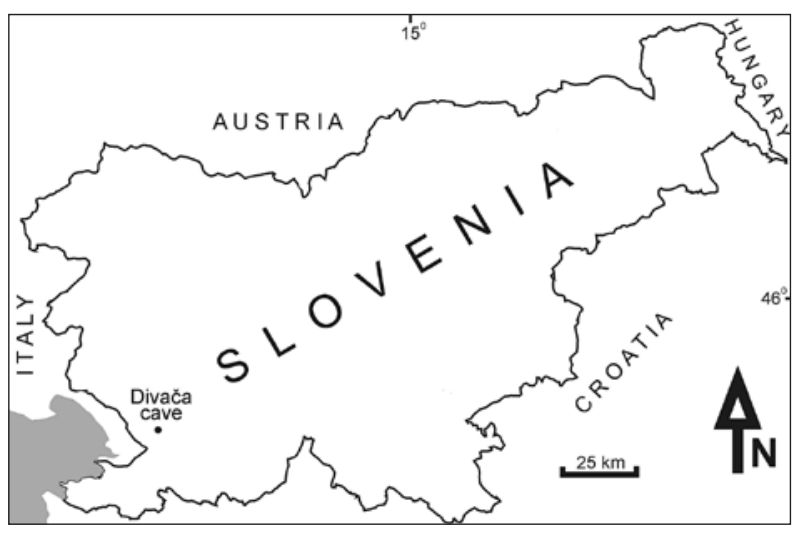

Fig. 1: Location of the Divača cave.

the length of $610 \mathrm{~m}$. They extend from $12 \mathrm{~m}$ to $60 \mathrm{~m}$ below the surface. A series of GPR profiles was measured across the known galleries of the cave as well as across the extension of the main axis of the cave towards the NE where no galleries are known. Different aspects of the data acquisition and processing were analysed and results compared with speleological data. Verification of the methodology for cavities detection in medium depth range is important for the future infrastructure projects in Slovenian karst, such as a new railway Divača-Koper, where several long tunnels through karstified limestone are planned. Several examples are known where even large cavities were discovered during tunnel constructions. In the case of Učka tunnel (Istra, Croatia) the discovered cave required to build even a special construction which supports the tunnel tube (Božičević 1995). 


\section{THE DIVAČA CAVE}

The Divača cave is an important cave in the Divača karst (Mihevc 2001). It was in details surveyed and investigated from speleological and geological point of view by Gospodarič (1985). Its entrance is $1 \mathrm{~km} \mathrm{SW}$ from Divača at the elevation of $427 \mathrm{~m}$ (Fig. 1). Its main gallery is $610 \mathrm{~m}$ long and extends between elevation $360 \mathrm{~m}$ and $390 \mathrm{~m}$ in NE-SW direction (Figs. 2 \& 3). This is $200 \mathrm{~m}$ above the actual flow of the underground Reka River in nearby Kačna cave and in Škocjanske cave. The total length of the surveyed polygon is $707 \mathrm{~m}$ and the maximum depth $75 \mathrm{~m}$. The main gallery is from $5 \mathrm{~m}$ to $15 \mathrm{~m}$ wide and the roof of a cave reach a maximum height of $20 \mathrm{~m}$. The main gallery is located from $12 \mathrm{~m}$ to $60 \mathrm{~m}$ below the surface. The surface above the cave is generally flat, but contains several dolines. It is covered by a quite dense forest and bushes.

The area of Divača cave is built of Late Cretaceous micrite and sparite bedded limestone of Turonian age. The strata are dipping in the first half of the cave (NE part) for $15-20^{\circ}$ towards the south-west and in the second half (SW part) for $15-20^{\circ}$ towards the south. The rock in the area is tectonically fractured but not crushed (Gospodarič 1985). The largest tectonic feature in vicin- ity is a NW-SE trending right-lateral strike slip Divača fault which runs approximately $1 \mathrm{~km}$ to the NE from the cave (Placer 1981).

Divača cave is characterized by extensive infill of sediments which completely cover the cave floor. Prevailing is flowstone in forms of different speleothems, but there are also several fluvial sediments (red loam and sand) and rockfall boulders. In the SW the cave ends in Žiberna hall, close to Trhlovca cave which is located above this hall (Fig. 3). In the NE where the entrance to the cave is located (Fig. 3) the floor in the entrance hall is covered manly by collapsed blocks and rubble (Gospodarič 1985). Extension of the cave gallery towards $\mathrm{NE}$ is very probable, but blocked by sediments and collapse material at the entrance shaft.

Electrical resistivity imaging was recently conducted above the Divača cave and its continuation in denuded cave located to the NE on slopes of Radvanj collapse doline (Mihevc \& Stepišnik 2011). Empty cave passages were not detected, presumably as electric resistivity contrast between voids and high resistant carbonate is too small. On the other hand, denuded caves and cave sections filled with loam can be clearly distinguished.

\section{THE GROUND PENETRATING METHOD AND CAVITY DETECTION}

After earlier applications of ground penetrating radar (GPR) method in specific conditions of permafrost and ice covered areas, the method has started to develop rapidly for investigations of the shallow subsurface around 25 years ago (Davis \& Annan 1989). The method has been successfully applied to solve various geological, geotechnical, engineering and archaeological problems in a depth range from few centimetres to several tens of meters or even hundred of meters in case of penetrating the ice. Among geological problems the most common applications are related to the investigations of the bedrock depth, stratigraphy and sedimentology of sediments, faults and fracture zones, delineation of rock fabric, determination of water table depth, identification of karst features and detection of voids (Reynolds 1997; Daniels 2004; Jol 2009).

The principle of GPR method is that a short pulse of high frequency $(25-2,000 \mathrm{MHz})$ electromagnetic (EM) energy is transmitted into the ground where it is reflected from the interfaces which separates layers with different electrical properties. The reflected signal is detected by the receiver antenna, amplified, digitized and stored for later data processing. The GPR is normally used in a common-offset reflection mode using pair of properly spaced antennas which are moved along the straight measuring profile.

Propagation of EM waves trough the rocks is controlled by dielectric and conductivity properties of the material. The velocity of wave propagation $V$ in low-loss geologic materials depends on the relative dielectric permittivity (dielectric constant) $\varepsilon$ by equation

$\mathrm{V}=\frac{c}{\sqrt{\varepsilon}}$

where

$c=3 \cdot 10^{8} \mathrm{~m} / \mathrm{s}$ or $30 \mathrm{~cm} / \mathrm{ns}$, the propagation velocity of EM waves in vacuum.

On the other hand, the attenuation of EM waves depends mainly on the conductivity of material. Since the presence of water in rocks is the main factor which controls the conductivity, GPR method is most suitable for dry rocks where greatest depth of penetration can 
be achieved. Second factor which contrails the depth of penetration and data resolution is the frequency of the EM signal. Antennas which transmits and receives signals with different central frequencies should be therefore used for different purposes.

Detection of underground voids is quite a typical application of the GPR method. It can be used to assess geotechnical hazards related to the sudden collapse of natural or artificial cavities like abandoned mines or other underground excavations (Benson 1995). It is widely used also in archaeology to detect underground chambers which can have a significant archaeological meaning such as vaults, culverts and crypts (Reynolds 1997; Daniels 2004). Natural cavities and sinkholes which pose potential hazards can be related to the dissolution of various materials like salt and anhydrite (Frumkin et al. 2011), but most frequently they are characteristically for karstified limestone (Sharma 1997; McMechan et al. 1998; Chamberlain et al. 2000; Pueyo-Anchuela et al. 2009). Cavities can be formed also inside man maid structures like dikes and dams by dissolution and erosion where they can also be detected by GPR (Xu et al. 2010) and thus prevent the related hazards.
Most frequently detection of shallow cavities (depth smaller then $10 \mathrm{~m}$ or even smaller then $5 \mathrm{~m}$ ) is described in literature. This is understandable, because shallow features pose the main hazard for any surface construction or are interesting from the archaeological point of view. High frequency GPR systems in the range from 200 $\mathrm{MHz}$ to $500 \mathrm{MHz}$ are therefore usually applied, because they have appropriate depth penetration, but retain a good spatial resolution needed to detect also small cavities. But for specific projects, such as a tunnel construction through karstified rock, it is important to detect also larger cavities at greater depths. For medium depth range of up to $40 \mathrm{~m}$, this can be accomplished by application of low frequency (25-100 MHz) GPR systems. However, classical rigid low frequency antennas are quite large and their application is thus very difficult or even impossible in a rough terrain with dense vegetation which is usually encountered in karst areas. Application of low frequency GPR for cavities detection in a medium depth range is therefore a challenge, which is analysed in this study.

\section{DATA AQUISITION}

To asses the capabilities of low frequency GPR and to investigate the possible existence of unknown cave galleries $\mathrm{NE}$ of the Divača cave entrance, we planned 16 profiles oriented in NW-SE direction, which is in general perpendicular to the axis of the main cave gallery. First of all start and end point of planned profiles were marked in the field with the help of a portable GPS receiver. Secondly all the profile locations were carefully inspected to assess the possibility to traverse the field with GPR in approximately straight direction. This field inspection has shown that measurement along some profiles is not possible, mainly due to very dense bushes. At the end we decided to measure seven profiles across the known cave gallery and four profiles NE to the entrance where no cave passages are known yet (Fig. 2). The length of the each profile is between $150 \mathrm{~m}$ and $190 \mathrm{~m}$. The surface above the cave is relatively flat although there are some dolines. On the other hand, microtopography is quite rough because of several rocks in the ground, some rock fences and dense vegetation. We decided not to perform a topographic survey of elevation changes along the profiles, because detailed survey would take much more time than GPR acquisition itself, and because it is difficult to correct the profile for small topographic features when spacing between antennas is $4 \mathrm{~m}$. On the other hand, single receiver GPS applied for position does not provide elevation data of sufficient accuracy. Our aim was therefore to asses the capability of the method without performing topographic correction.

Data were acquired using Mala ProEx GPR recording unit with $50 \mathrm{MHz}$ antennas using common offset technique. Special rough terrain antennas (RTA) recently developed by Mala were used. Specific to these antennas with respect to normal unshielded antennas which should be oriented perpendicular to the profile direction and are rigid, is that RTA are flexible, in-line oriented, all-in-one antennas (Mala 2010). The flexible "snake" like design in form of a long tube allows the antenna to be manoeuvred easily and efficiently through the dense vegetation or uneven terrain without affecting ground contact, providing optimum results also in difficult environment. The most important benefit is that it isn't necessary to clear the profile route prior to the survey. The total length of $50 \mathrm{MHz}$ RTA is $9.25 \mathrm{~m}$ and the spacing between antennas $4 \mathrm{~m}$. A nominal penetration depth of $50 \mathrm{MHz}$ acquisition system is according to different authors between $25 \mathrm{~m}$ and $40 \mathrm{~m}$ (Reynolds 1997; Daniels 2004; Jol 2009; Mala 2010). 


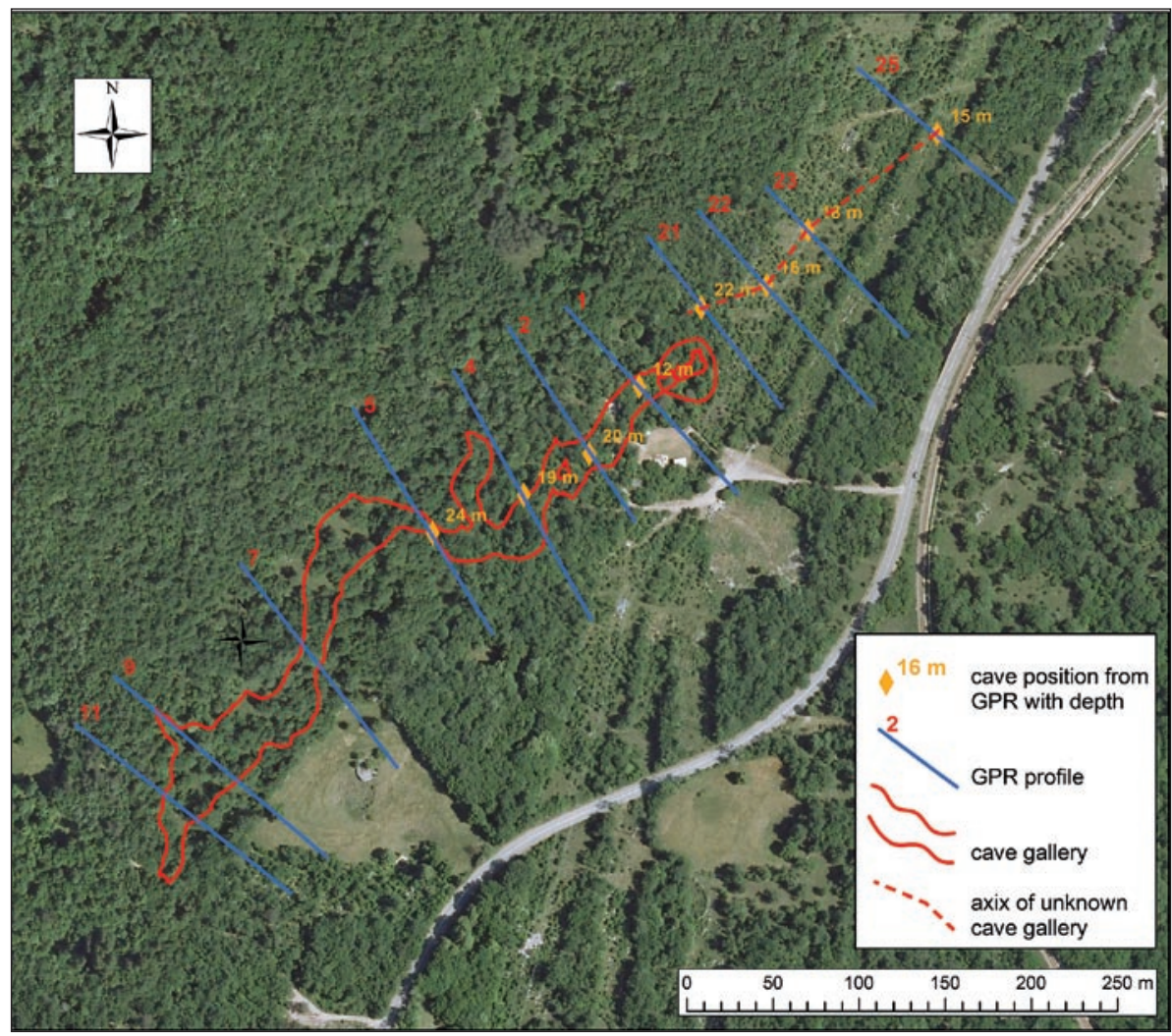

Fig. 2: Position map of GPR profiles and schematic presentation of Divača cave ground plan. Locations where the main cave gallery was revealed by GPR are indicated. Aerial image after Surveying and mapping authority of Slovenia (GURS).
To trigger acquisition in regular intervals two different systems are used in common GPR systems. First is a distance-measuring wheel which is used with highfrequency all-in-one antennas that are towed or pushed along the profile. Second is a chain (leash) profile encoder composed of a leash and a wheel which is rotated by unwrapping of the leash and triggers the acquisition in regular distance intervals. Unfortunately, this system is also not suitable for rough terrain with dense vegetation. Therefore we decided to use time interval trigger and GPS receiver attached to the acquisition unit. The profile is measured at as much constant velocity of movement along the profile as possible, and the data recorded at fixed time interval, $0.2 \mathrm{~s}$ in our case. As GPS receiver marks

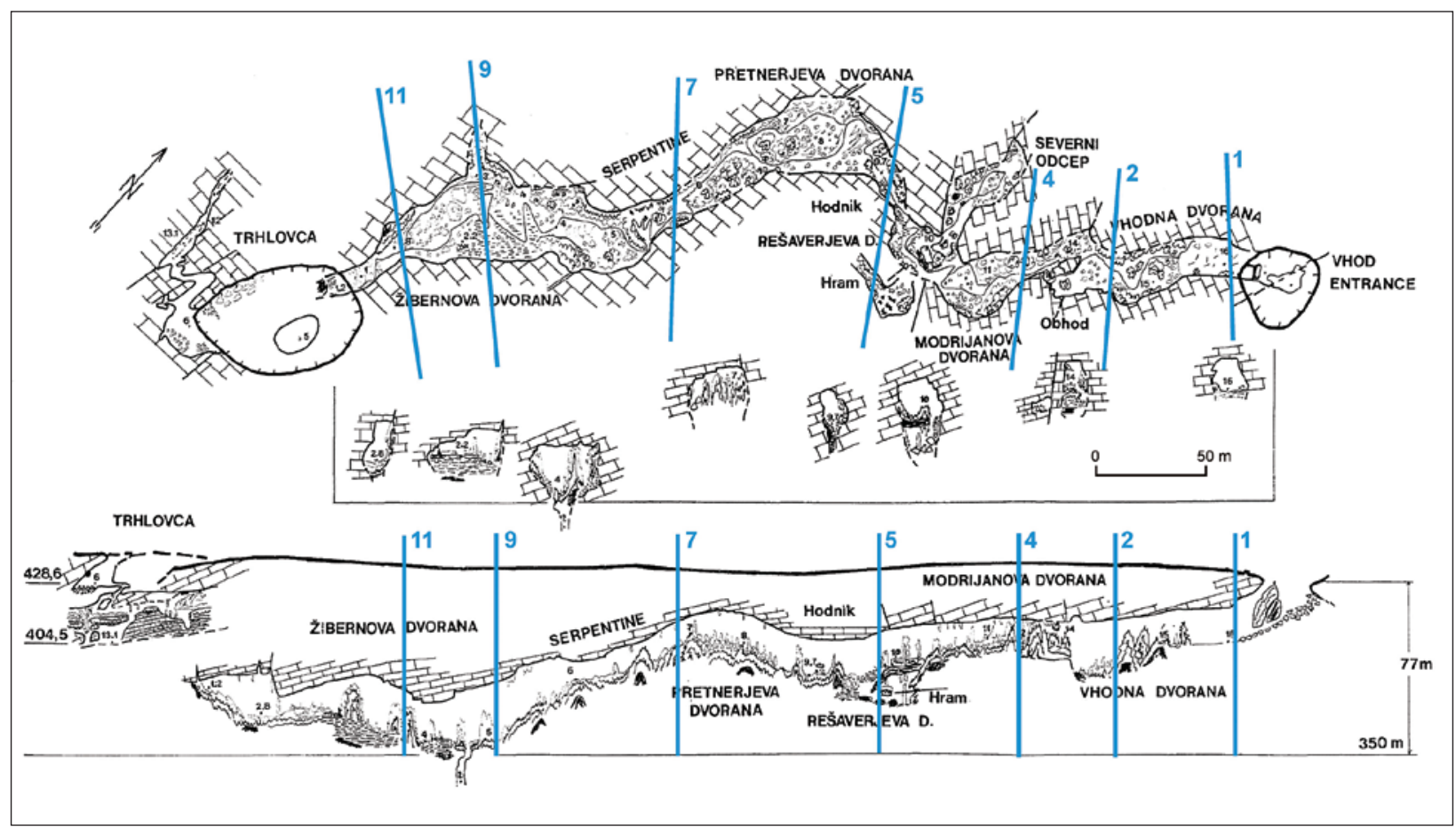

Fig. 3: Divača cave ground plan and longitudinal section with some cross sections (after Gospodarič 1985). Blue lines indicate locations of GPR profiles. 
each recorded trace with coordinates, it is possible to later adjust any uneven progress along the profile during measurement by trace interpolation. We succeeded to perform measurements quite smoothly, since trace interpolation has given average spacing between traces from $0.19 \mathrm{~m}$ to $0.22 \mathrm{~m}$ for different profiles, which is a rather small scatter. Marking traces with GPS coordinates was very important also to exactly determine the locations of interpreted features in processed profiles.

Acquisition parameters are summarized in Tab. 1. Sampling interval was $1 \mathrm{~ns}$ and the acquisition window length 1024 ns. Data were acquired after a longer period (two weeks) without precipitations. The surface soil layer and limestone beneath were therefore relatively dry. All the
Tab. 1: GPR acquisition parameters.

\begin{tabular}{r|l}
\hline Antennas: & $\begin{array}{l}50 \mathrm{MHz} \text { unshielded rough } \\
\text { terrain antennas (RTA) }\end{array}$ \\
\hline Antenna separation: & $4 \mathrm{~m}$ \\
\hline Sampling frequency: & $1000 \mathrm{MHz}$ \\
\hline Sampling interval: & $1 \mathrm{~ns}$ \\
\hline Acquisition window length: & 1024 samples $=1024 \mathrm{~ns}$ \\
\hline Stacks: & 16 \\
\hline Trig interval: & $0.2 \mathrm{~s}$ \\
\hline Average trace spacing: & $0.19-0.22 \mathrm{~m}$
\end{tabular}

profiles presented in continuation (Figs. 4-14) are shown in direction NW on the left side and SE on the right side, independent of the actual direction of acquisition.

\section{DATA PROCESSING}

Data were processed using a processing sequence shown in Tab. 2. Spatial interpolation of traces which follows DC correction and time zero adjustment was based on the GPS signal recorded together with traces and enabled equal distance presentation of results as explained in the previous section. Clear diffractions observed in profiles, which correspond to the cave locations, were used for velocity determination by hyperbola fitting (e.g. Fig. 4b). Average value of velocities from different profiles has given the value of $11.3 \mathrm{~cm} / \mathrm{s}$ which corresponds to the dielectric constant $\varepsilon=7$. This figure corresponds well to the central value for a dry limestone from the literature where the $\varepsilon$ span from 4 to 9 (Reynolds 1997; Daniels 2004; Jol 2009). Predictive deconvolution was used only optionally and for comparison, since it did not contribute to the better image of the subsurface. Stolt F-K migration using established velocity of $11.3 \mathrm{~cm} / \mathrm{s}$ was also used
Tab. 2: GPR profiles processing sequence.

\begin{tabular}{l}
\hline DC removal \\
\hline Time zero adjustment \\
\hline Spatial interpolation \\
\hline Background removal \\
\hline Amplitude correction (AGC) \\
\hline Bandpass filtering \\
\hline Hyperbola fitting for velocity determination \\
\hline Time to depth conversion \\
\hline
\end{tabular}

only for comparison and not for interpretation. Example in Fig. 4c clearly shows its effect on the diffraction hyperbola caused by a cave. Time to depth conversion was performed using constant velocity of $11.3 \mathrm{~cm} / \mathrm{s}$ since no lithological changes are expected along the investigated depth of penetration.

\section{VERTICAL AND HORIZONTAL RESOLUTION}

It is well known that there is a trade off between the desired depth of GPR penetration and spatial resolution of the data. A compromise is thus always needed.

Vertical resolution $(\mathrm{Vr})$ is normally better understood, since it is directly related only to the wavelength. It is given by

$$
V r=\frac{T p u l s e c}{2 \sqrt{\varepsilon}}
$$

where

Tpulse - transmitted pulse duration; inversion of antenna centre frequency,

$c=3 \cdot 10^{8} \mathrm{~m} / \mathrm{s}$ or $30 \mathrm{~cm} / \mathrm{ns}$, the propagation velocity of EM waves in vacuum,

$\varepsilon$ - relative dielectric permittivity (dielectric constant).

Horizontal resolution $\mathrm{Hr}$ ) is a topic of much debate and different authors give different opinion on what 
should be the right way of calculating the horizontal resolution. Basically it depends on the following parameters:

- the number of traces per unit distance,

- the beam width of the antenna,

- the spacing between transmitting and receiving antenna,

- the depth of the object.

Following is the relation which according to Alvarez-Cabrera (2011) fits best the results in real conditions

$H r=\frac{c}{4 f \sqrt{\varepsilon}}+\frac{D}{\sqrt{\varepsilon+1}}$

where

$f$ - central frequency of the antenna,

$D$ - depth to the plane where the two objects to be distinguished are located.

$c=3 \cdot 10^{8} \mathrm{~m} / \mathrm{s}$ or $30 \mathrm{~cm} / \mathrm{ns}$, the propagation velocity of EM waves in vacuum,

$\varepsilon$ - relative dielectric permittivity (dielectric constant).
Tab. 3: Vertical and horizontal resolution of $50 \mathrm{MHz}$ acquisition system in limestone.

\begin{tabular}{|c|c|c|c|}
\hline \multicolumn{3}{|c|}{ Centre frequency: } & $50 \mathrm{MHz}$ \\
\hline \multicolumn{3}{|c|}{ Wavelength $(\lambda)$ in air: } & $6 \mathrm{~m}$ \\
\hline \multicolumn{3}{|c|}{ Dielectric constant $(\varepsilon)$ of limestone: } & 7 \\
\hline \multicolumn{3}{|c|}{ EM velocity in limestone: } & $11.3 \mathrm{~cm} / \mathrm{ns}$ \\
\hline \multicolumn{3}{|c|}{ Wavelength in limestone: } & $2.3 \mathrm{~m}$ \\
\hline Depth (m) & Vertical resolution $(\mathrm{m})$ & \multicolumn{2}{|c|}{ Horizontal resolution $(\mathrm{m}$} \\
\hline 10 & 1.1 & \multicolumn{2}{|c|}{4.1} \\
\hline 20 & 1.1 & \multicolumn{2}{|l|}{7.6} \\
\hline 30 & 1.1 & \multicolumn{2}{|l|}{11.2} \\
\hline 40 & 1.1 & \multicolumn{2}{|l|}{14.7} \\
\hline
\end{tabular}

Although this relation is not exact and due to all the factors influencing the horizontal resolution, it gives only a good approximation on what to expect.

For the $50 \mathrm{MHz}$ antennas used and limestone with $\varepsilon=7$, vertical and horizontal resolutions according to equations (2) and (3) for four different depths are given in Tab. 3. Considering the dimensions of the Divača cave main gallery (Fig. 3) it seems that the horizontal resolution of applied system is sufficient at least down to the depth of $30 \mathrm{~m}$ where it is still around $11 \mathrm{~m}$

\section{RESULTS AND INTERPRETATION}

Processed GPR profiles acquired across the known cave gallery are shown in Figs. 4-10 and profiles acquired NE of the cave entrance in Figs. 11-14. The locations of the profiles are shown in Figs. 2 \& 3. All the profiles were processed using processing sequence listed in Tab. 2. For some of the profiles velocity analysis using hyperbola fitting to the diffraction caused by a cave is also shown. Only for profile 1 results of Stolt F-K migration are also shown (Fig. 4c). All the profiles are shown down to the 700 ns two-way-traveltime which corresponds to the depth of $40 \mathrm{~m}$. Although the data were recorded in 1000 $\mathrm{ms}$ long window, no interpretable features are visible in the lower most part between $700 \mathrm{~ms}$ and $1000 \mathrm{~ms}$.

In profile 1 (Fig. 4) recorded close to the entrance of the cave the gallery is very clearly visible with its roof at the depth of $12 \mathrm{~m}$. Some reverberations (Kofman et al. 2006) inside the open space are visible both on unmigrated (Fig. 4a) and migrated (Fig. 4c) profile. Another distinct feature is a doline characterized by a low-frequency signal due to red loam and soil infill at its bottom. By four small arrows locations of four additional unknown cavities are shown. They are located at the depth from $10 \mathrm{~m}$ to $20 \mathrm{~m}$. The cave gallery with its roof at $20 \mathrm{~m}$ depth is also clearly visible in profile 2 (Fig. 5). It corresponds to the entrance hall of the cave and the established depth is in agreement with the cave longitudinal section (Fig. 3). The width of the gallery is around $10 \mathrm{~m}$. Additional smaller cavities indicated by arrows are located at the depth between $8 \mathrm{~m}$ and $16 \mathrm{~m}$. In profile 4 (Fig. 6) the cave gallery is less clear. Its roof is at $19 \mathrm{~m}$ depth. According to the ground plan and crosssections (Fig. 3) the gallery is here very narrow (less then $10 \mathrm{~m}$ ) which is presumably the main reason for a weaker response. Interesting feature is a dipping horizon in the NW part of the profile. It is most probably related to the side gallery called Severni odcep (Fig. 3). Several cavities located relatively deep are visible in profile 5 (Fig. 7). The main gallery has a roof at the depth of $24 \mathrm{~m}$. NW of its location there are at least three additional cavities at the depth between $19 \mathrm{~m}$ and $25 \mathrm{~m}$. Also a clear deep feature at the NW end of the profile is most probably a cave located at the depth of $32 \mathrm{~m}$. The response of GPR is less clear in profile 7 (Fig. 8) and the main gallery can not be interpreted with confidence although three marked features are most probably caused by cavities. According to the ground plan (Fig. 3) the gallery is here very narrow, 

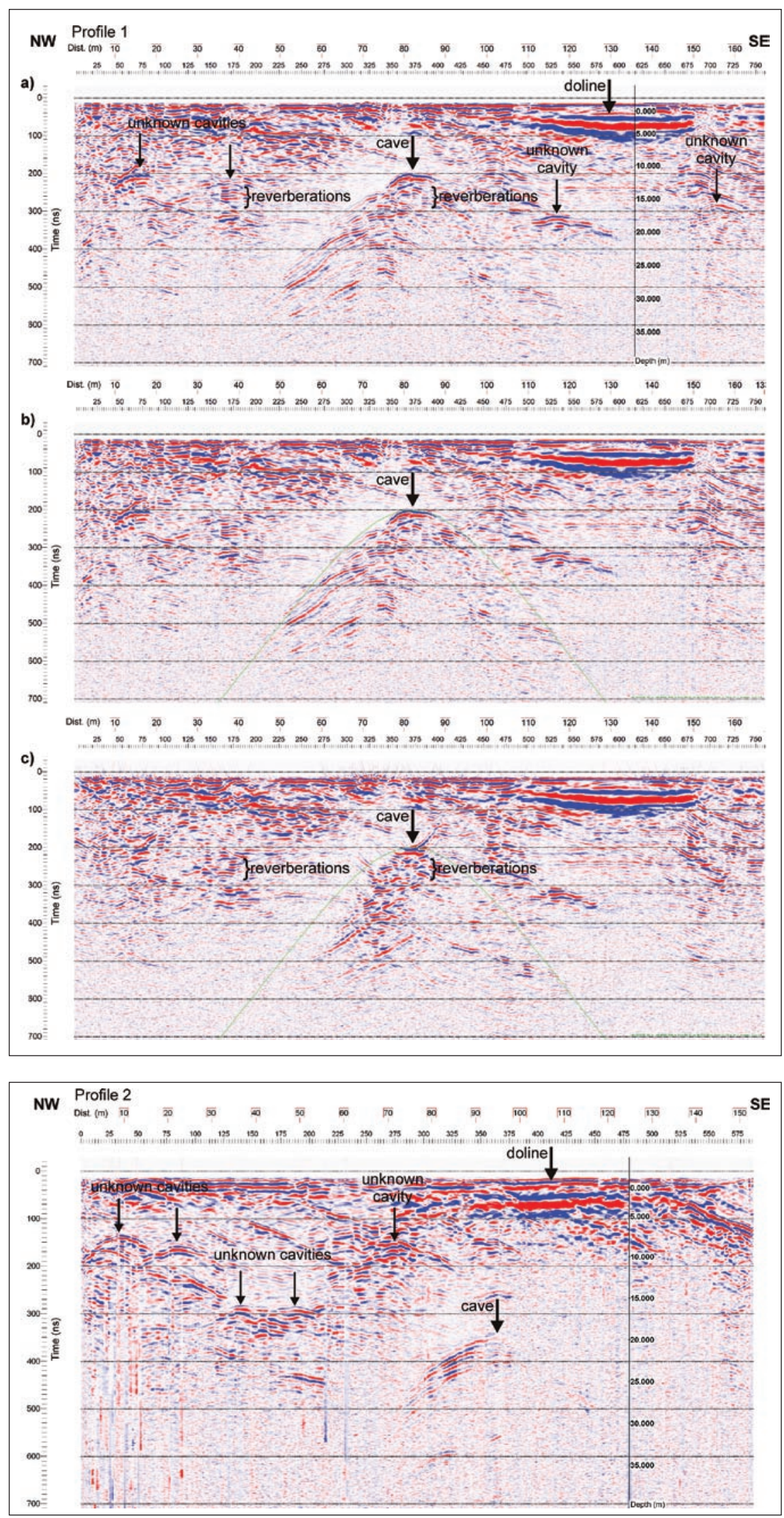

Fig. 4: GPR Profile 1 a) with time and depth scale, b) with hyperbola fitted to the diffraction caused by a cave, $c$ ) after Stolt F-K migration.
Fig. 5: GPR Profile 2 with time and depth scale. 
ANALYSIS OF THE CAPABILITIES OF LOW FREQUENCY GROUND PENETRATING RADAR FOR CAVITIES DETECTION ...
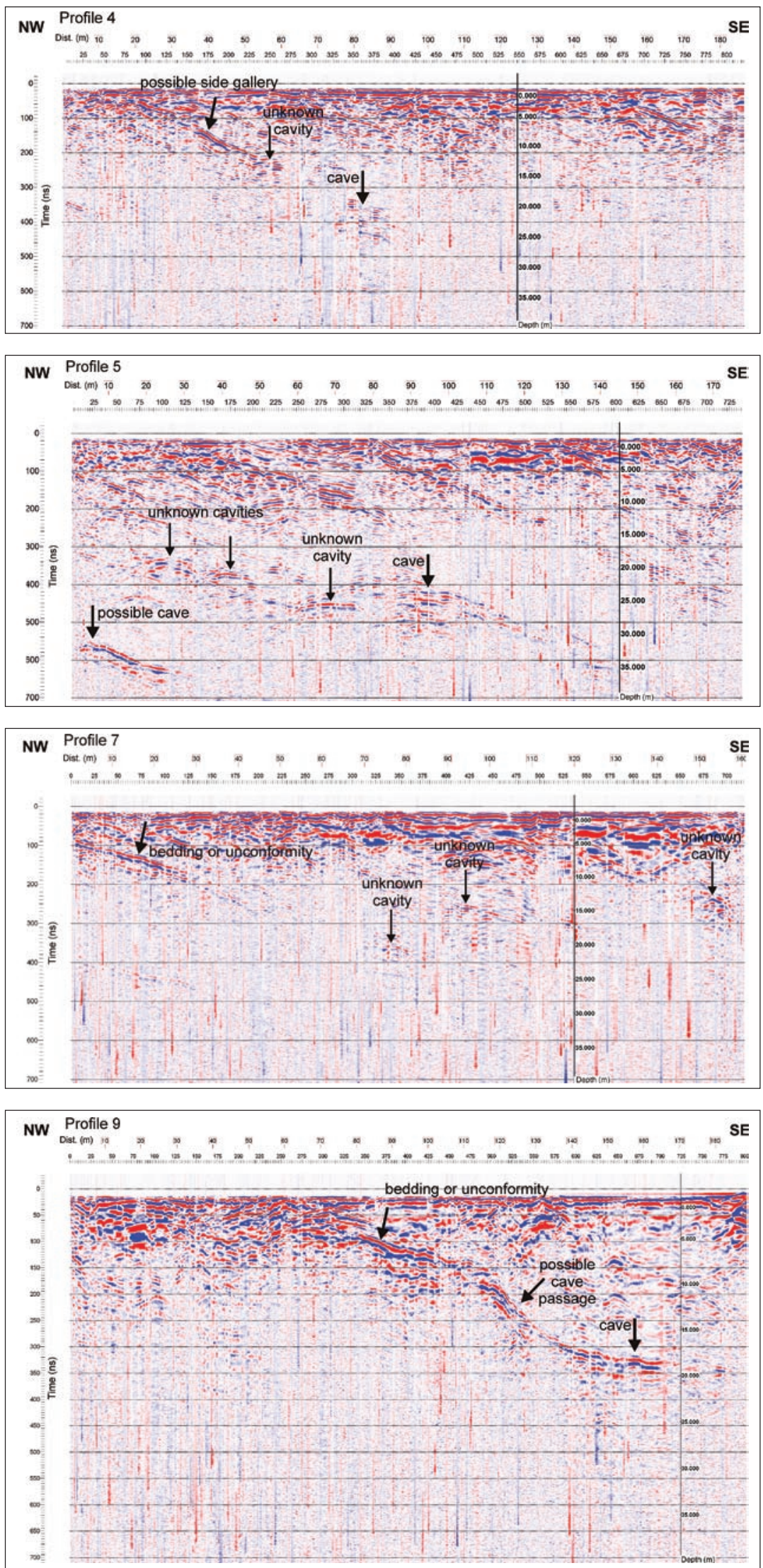

Fig. 6: GPR Profile 4 with time and depth scale.

Fig. 7: GPR Profile 5 with time and depth scale.

Fig. 8: GPR Profile 7 with time and depth scale.

Fig. 9: GPR Profile 9 with time and depth scale. 

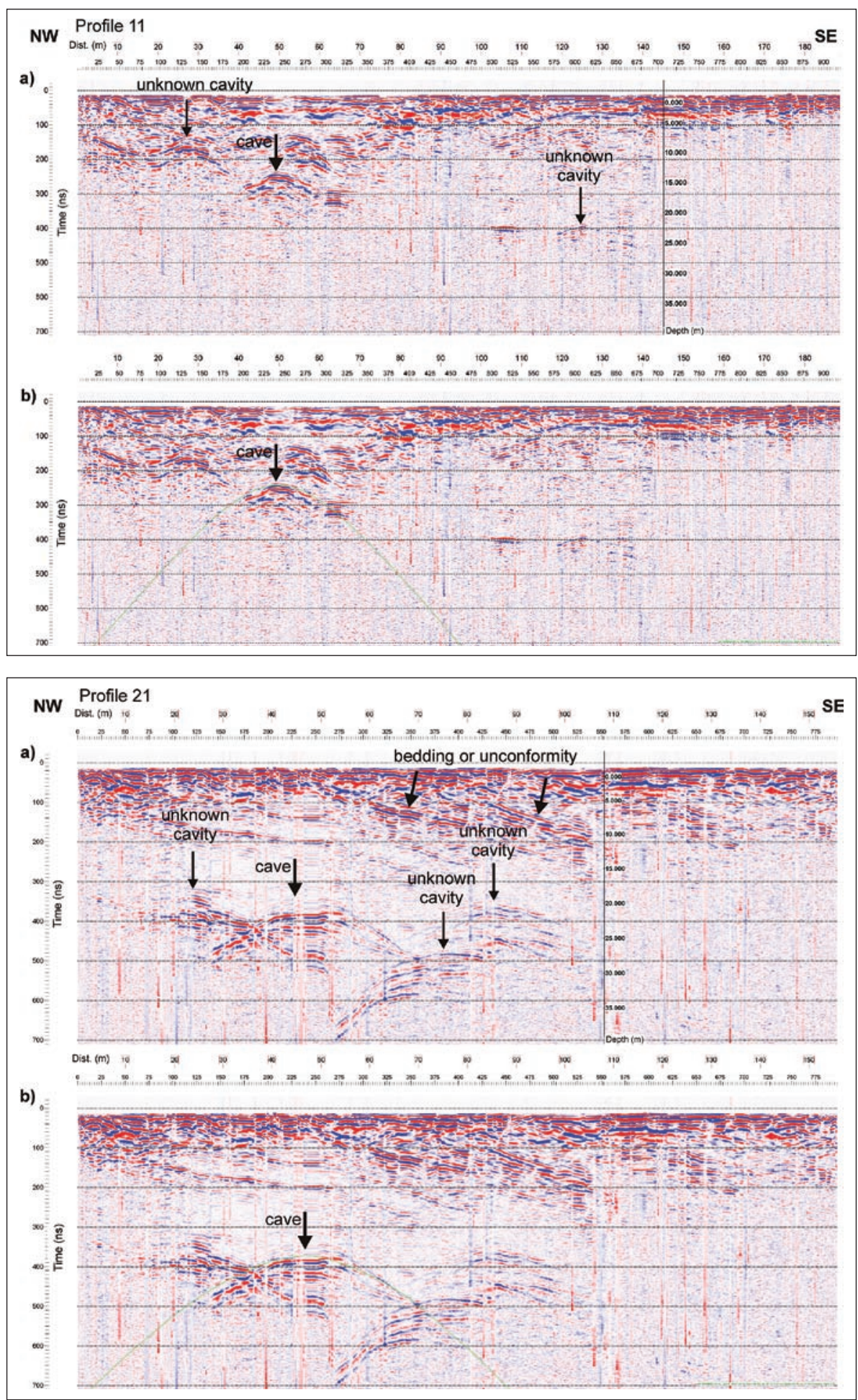

Fig. 10: GPR Profile 11 a) with time and depth scale, b) with hyperbola fitted to the diffraction caused by a cave.
Fig. 11: GPR Profile 21 a) with time and depth scale, $b$ ) with hyperbola fitted to the diffraction caused by a cave. less than $10 \mathrm{~m}$ wide. A dipping horizon at the NW end of the profile is perhaps caused by bedding or unconformity inside the limestone. Profile 9 (Fig. 9) was acquired across the widest part of the Žiberna hall. According to GPR data the gallery roof is at the depth of $18 \mathrm{~m}$ which is too shallow with respect to longitudinal cave section. It is possible that an unknown cave was detected and that the main gallery which should be at the depth of around $40 \mathrm{~m}$ remains unrevealed. There are also two horizons dipping in SE direction. The first one in the shallow part is most probably related to the bedding or unconformity and the second more steep one to the unknown cave 

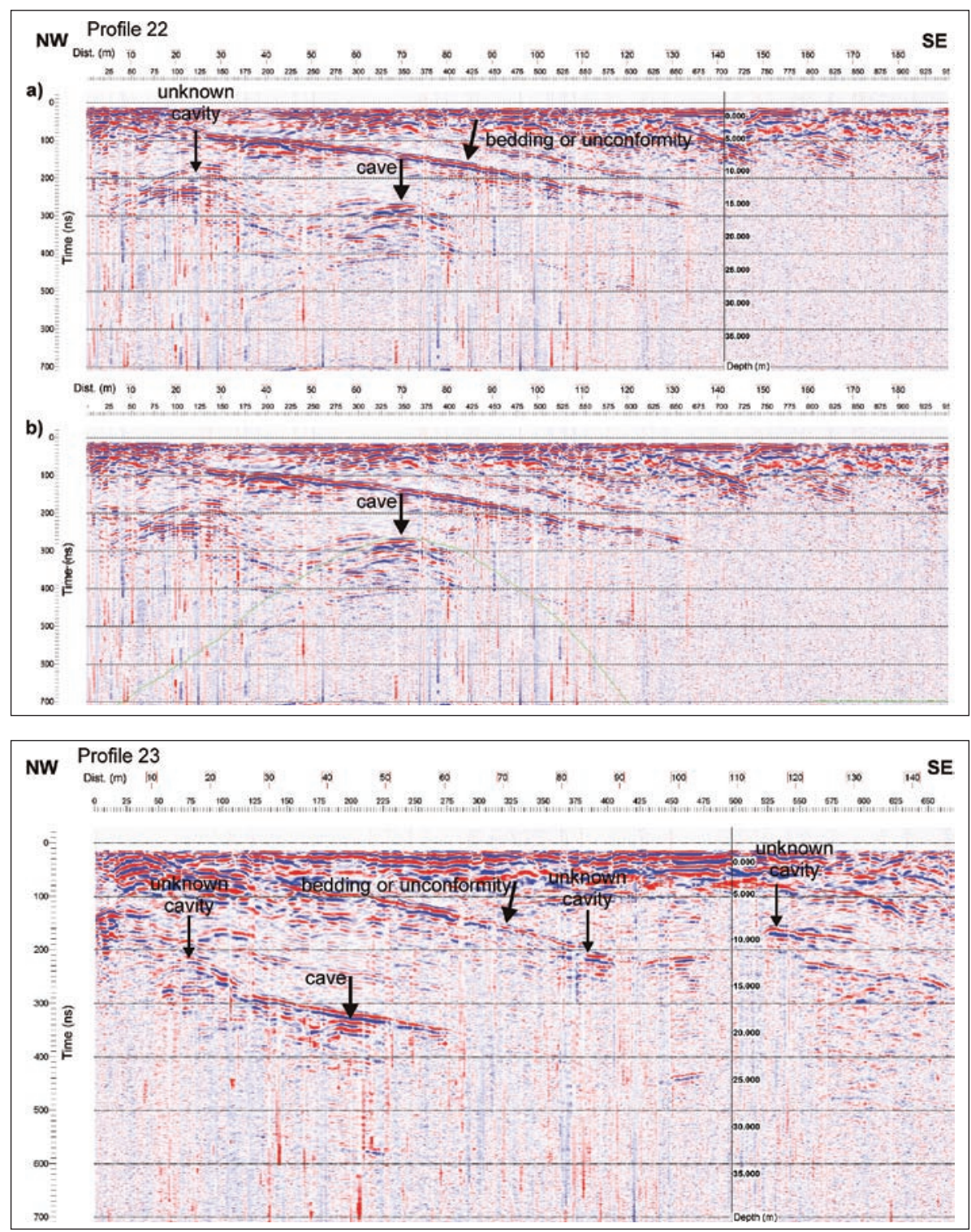

Fig. 12: GPR Profile 22. a) with time and depth scale, $b$ ) with hyperbola fitted to the diffraction caused by a cave.

Fig. 13: GPR Profile 23 with time and depth scale. passage, because underneath there is according to the ground plan a side gallery. Two shallow caves are clearly visible at the depth between $10 \mathrm{~m}$ and $15 \mathrm{~m}$ in profile 11 (Fig. 10), as well as a feature most probably related to the cavity at the depth of $22 \mathrm{~m}$. At larger depths no cavities were imaged, but the profile is located near the SW end of the cave where the gallery is less than $10 \mathrm{~m}$ wide. Locations where the main cave gallery was revealed in all recorded profiles are shown in Fig. 2 and coincide very well with the actual location of the cave gallery.

Profiles 21-25 were recorded NE of the cave entrance across the prolongation of the axis of the main cave gallery when no accessible cavities are known. In profile 21 (Fig. 11), there are four clear diffractions visible which are interpreted as unknown cavities. The most prominent feature is interpreted as a continuation of the main gallery at the profile distance of $45 \mathrm{~m}$ and at the depth of $22 \mathrm{~m}$. In the shallow part two horizons dipping to the SE are visible which can be interpreted as beddings or unconformities in the limestone. Profile 22 (Fig. 12) also reveals a clear cavity at the profile distance of $70 \mathrm{~m}$ and at the depth of $16 \mathrm{~m}$. Additional cavity is very probable at the profile distance of $25 \mathrm{~m}$ and at the depth of $11 \mathrm{~m}$. Clear bedding or unconformity horizon dipping toward SE is also visible. In profile 23 (Fig. 13) the main cavity is most probably located at the profile distance of $45 \mathrm{~m}$ and the depth of $18 \mathrm{~m}$, but it is slightly masked by onlaping horizon. It is not impossible that also this horizon is related to larger underground chamber, because it is limited in space, in contrast to the more shallow dipping horizon which is much longer. Additional smaller cavities are probable at marked locations. Profile 25 


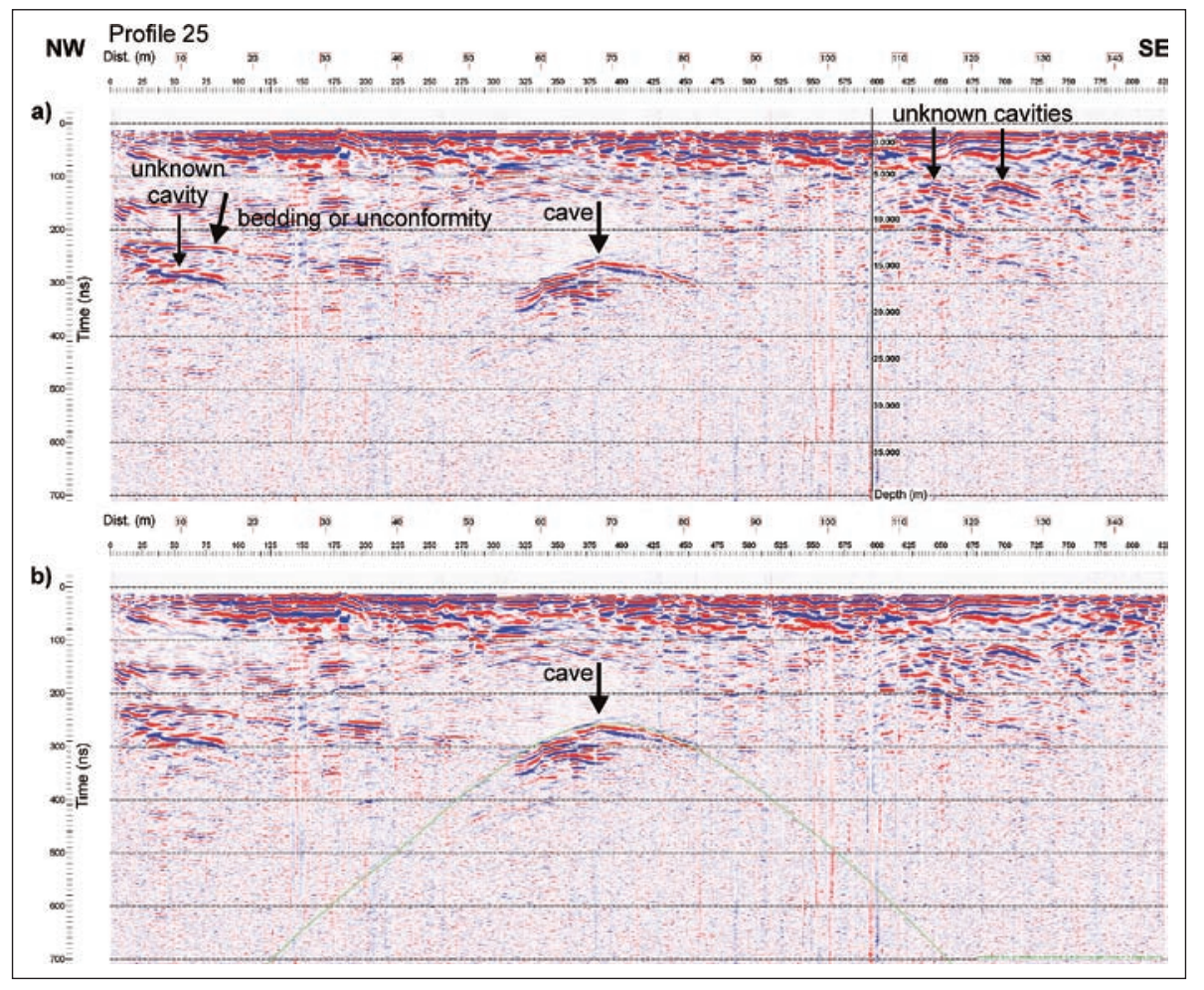

Fig. 14: GPR Profile 25 a) with time and depth scale, $b$ ) with hyperbola fitted to the diffraction caused by a cave.

(Fig. 14) reveals very clearly a cavity at the profile distance of $70 \mathrm{~m}$ and at the depth of $15 \mathrm{~m}$. Some smaller cavities indicated by diffractions are probable at both ends of the profile.

The extent of unknown gallery can be clearly deduced by the interpolation between the markers shown in Fig. 2. In this area an anomaly with low resistivity was obtained by electric resistivity imaging which was interpreted as a cave gallery filled with loam (Mihevc \& Stepišnik 2011). From georadar data alone it is not possi- ble to deduce with confidence whether or not the detected galley is filled with sediments. However, since diffractions are very clear and similar to the features observed across the known cave, and include also prominent reverberations, it is more probable that we are dealing with open gallery. Therefore, the single resistivity profile from this part should be supplemented by additional profiles measured along existing georadar profiles to provide additional insight into this question.

\section{CONCLUSIONS}

Low frequency GPR have proved to be a very effective tool to detect larger cavities located at medium depths. The known main gallery of the Divača cave was clearly imaged in the NE part of the cave where the roof of the gallery is located at the depth from $10 \mathrm{~m}$ to $30 \mathrm{~m}$ and the width of the open space is mainly around $10 \mathrm{~m}$. In the SW part of the cave the gallery is located deeper than $30 \mathrm{~m}$, reaching the maximum depth of $60 \mathrm{~m}$. In this part the performed measurements were not able to image the main cave gallery. This is most probably related to the limit of the depth penetration of $50 \mathrm{MHz}$ system although the conditions were favourable, because it is expected that the limestone above the cave was relatively dry during measurements. Since the main cave gallery has a width between 5 and $15 \mathrm{~m}$, the horizontal resolution should generally not be a problem at the depth of down to $40 \mathrm{~m}$, but can limit the system capabilities at larger depth, especially where the gallery is less then $10 \mathrm{~m}$ wide. Although the main gallery was not imaged in this part, several shallower cavities were detected which were previously unknown. Testing of $25 \mathrm{MHz}$ antennas, currently not available to us, is recommended as a next step to increase the depth penetration, but the spatial resolution at greater depths can limit the success in detection of a gallery in this case. 
The most important result of this study is that the profiles acquired $\mathrm{NE}$ of the cave entrance revealed very clearly the existence of an unknown gallery which is located at the depth between $15 \mathrm{~m}$ and $22 \mathrm{~m}$ (Fig. 2). From the speleogenetic point of view (Gospodaric 1985; Mihevc 2001; Mihevc \& Stepišnik 2011) continuation of the cave in this direction is expected. Access to unknown galleries is blocked by a collapsed material and other sediments at the entrance shaft. In addition to the main gallery which is visible in all profiles, some additional smaller cavities are also imaged. Additional speleological investigations are recommended to see if it is possible to reach the unknown galleries from either new entrances at the surface or from the entrance hall of the Divača cave, or to assess the feasibility if digging could result in a research progress.

High frequency GPR was already successfully applied in Slovenian karst in the past (Brezigar et al. 1995;
Trček et al. 2000; Knez \& Slabe 2005; Pavlič \& Praznik 2011). On the other hand, some important infrastructural projects will be realized in the next decade, which will enclose also the construction of several long tunnels in karstified limestone. Therefore, it would be very important to supplement other geophysical investigations in the future also with the low frequency GPR profiling for detection of cavities in medium depth range which represent a serious hazard for such projects (Šebela 2009). In addition to surface GPR investigations, it is recommended to apply also GPR measurements inside boreholes drilled vertically from the surface or horizontally ahead of the tunnel front for more detailed in-situ information which will secure a safe realization of a project. Low frequency GPR investigations are recommended also in a basic speleological research to direct the research efforts when searching for continuation of existing caves, especially to assess if digging is feasible.

\section{ACKNOWLEDGMENTS}

The project was realized with the support of research program P1-0011 financed by Slovenian Research Agency.
The author is indebted to Jure Hajna for a digital version of Divača cave ground plan.

\section{REFERENCES}

Alvarez-Cabrera, R., 2011: GPR Antenna Resolution. Geoscanners AB.- [Online] Available from: http:// www.geoscanners.com/pdf/antres.pdf [Accessed $2^{\text {nd }}$ December 2011].

Benson, A.K., 1995: Application of ground penetrating radar in assessing some geological hazards: examples of groundwater contamination, faults, cavities.J. of Applied Geophysics, 33, 177-193.

Božičević, S., 1995: Kaptaža u kaverni ispod tunela Učka.- In: Vlahović, I., Velić, I. \& M. Šparica (ed.) Vodič po ekskurziji na 1. hrvatskom geološkom kongresu, $18^{\text {th }}-21^{\text {th }}$ October 1995, Opatija, Croatia. Hrvatsko geološko društvo, 3-15, Zagreb.

Brezigar, A., Tomšič, B., Štern, J. \& G. Rašković, 1995: Georadar - visokoločljiva geofizikalna elektromagnetna naprava (Georadar - high resolution geophysical electromagnetic device).- Geologija, $37-38,437-458$.
Chamberlain, A.T., Sellers, W., Proctor, C. \& R. Coard, 2000: Cave detection in limestone using Ground Penetrating Radar.- J. of Archaeological Science, 27, 957-964.

Daniels, D.J., 2004: Ground Penetrating Radar.- The Institution for Electrical Engineers, pp. 726, London.

Davis, J.L. \& A.P. Annan, 1989: Ground-Penetrating radar for high-resolution mapping of soil and rock stratigraphy.- Geophysical Prospecting, 37, 5, 531551.

Frumkin, A., Ezerssky, M., Al-Zoubi, A., Akkawi, E. \& A.R. Abueladas, 2011: The Dead Sea sinkhole hazard: Geophysical assessment of salt dissolution and collapse.- Engineering Geology, 134, 102-117.

Gospodarič, R., 1985: O speleogenezi Divaške jame in Trhlovice (On the speleogenesis of Divaška jama and Trhlovca cave).- Acta Carsologica, 13, 5-32.

Jol, H.M., 2009: Ground Penetratig Radar: Theory and applications.- Elsevier, pp. 524, Amsterdam. 
Knez, M. \& T. Slabe, 2005: Non-destructive georadar researches in the area of road subsidence of motorway near Postojna, classical Karst, Slovenia.- Geophysical Research Abstracts, 7.

Kofman, L., Ronen, A. \& S. Frydman, 2006: Detection of model voids by identifying reverberation phenomena in GPR records.- J. of Applied Geophysics, 59, 284-299.

Mala, 2010: ProEx - Professional Explorer control unit, Operating manual.- Mala, pp. 60, Mala.

Mareš, S., Kelly, W.E. \& O. Mazač, 1997: Applied Geophysics in Environmental Engineering and Science.Universita Karlova, pp. 98, Prague.

McMechan, G.A., Loucks, R.G., Zeng, X. \& P. Mescher, 1998: Ground Penetrating Radar imaging of a collapsed paleocave system in the Ellenburber dolomite, central Texas.- J. of Applied Geophysics, 39, $1-10$.

Mihevc, A., 2001: Speleogenesis of Divača karst (Speleogeneza Divaškega krasa).- Založba ZRC, 27, pp. 180, Ljubljana.

Mihevc, A. \& U. Stepišnik, 2011: Uporaba metode električne upornosti tal na primeru Divaške jame. Dela, 35, 45-54.

Placer, L., 1981: Geološka zgradba jugozahodne Slovenije (Geological structure of southwestern Slovenia).Geologija, 24, 1, 27-60.
Pavlič, M.U. \& B. Praznik, 2011: Detecting karstic zones during highway construction using ground-penetrating radar.- Acta Geotech. Slovenica, 8, 1, 17-27.

Pueyo-Anchuela, O., Pocovi-Juan, A., Soriano, M.A. \& A.M. Casas-Sainz, 2009: Characterization of karst hazards from the perspective of the doline triangle using GPR -Examples from Central Ebro Basin (Spain).- Engineering Geology, 108, 225-236.

Reynolds, J.M., 1997: An Introduction to Applied and Environmental Geophysics.- Wiley, pp. 796, Chichester.

Sharma, P.V., 1997: Environmental and engineering geophysics.- Cambridge University Press, pp. 475, Cambridge.

Šebela, S., 2009: Caves as potential karst geohazards on highways in SW Slovenia.- Annales Ser. hist. nat., 19, 177-184.

Trček, B., Car, M. \& M. Veselič, 2000: The use of isotopic, hydrogeochemical and ground-penetrating radar investigations in the study of the unsaturated zone of the karst aquifer.- RMZ - Materials and geoenvironment, 47, 335-344.

Xu, X., Zeng, Q., Li, D., Wu, J. \& J. Shen, 2010: GPR detection of several subsurface voids inside dikes and dams.- Engineering Geology, 111, 31-42. 